\title{
The Effect of Silage and Concentrate Type on Intake Behavior, Rumen Function, and Milk Production in Dairy Cows in Early and Late Lactation
}

\author{
P. A. Abrahamse, ${ }^{* 1}$ B. Vlaeminck,, S. Tamminga, ${ }^{\star}$ and J. Dijkstra* \\ ${ }^{*}$ Animal Nutrition Group, Wageningen Institute of Animal Sciences, Wageningen University, PO Box 338, 6700 AH Wageningen, the Netherlands \\ †Laboratory for Animal Nutrition and Animal Product Quality, Ghent University, Proefhoevestraat 10, 9090 Melle, Belgium
}

\begin{abstract}
The objective of this experiment was to evaluate the effect of feeding total mixed rations (TMR) that differ in structural and nonstructural carbohydrates to dairy cows in early and late lactation on short-term feed intake, dry matter intake (DMI), rumen fermentation variables, and milk yield. A $5 \times 5$ Latin square experiment with 15 dairy cows was repeated during early and late lactation. The 5 treatments were a TMR with (all on dry matter basis) 55\% roughage (a 50:50 mixture of corn silage and grass silage) and $45 \%$ concentrate (a 50:50 mixture of concentrate rich in structural carbohydrates and concentrate rich in nonstructural carbohydrates; treatment CON), a TMR with the concentrate mixture and $55 \%$ grass silage (RGS) or $55 \%$ corn silage (RCS), and a TMR with the roughage mixture and $45 \%$ of the concentrate rich in structural carbohydrates (CSC) or the concentrate rich in nonstructural carbohydrates (CNS). Meal criteria, determined using the Gaussian-Gaussian-Weibull method per animal per treatment, showed an interaction between lactation stage and treatment. Feed intake behavior variables were therefore calculated with meal criteria per treatment-lactation stage combination. Differences in feed intake behavior were more pronounced between treatments differing in roughage composition than between treatments differing in concentrate composition, probably related to larger differences in chemical composition and particle size between corn silage and grass silage than between the 2 concentrates. The number of meals was similar between treatments, but eating time was greater in RGS $(227 \mathrm{~min} / \mathrm{d})$ and lesser in RCS $(177 \mathrm{~min} / \mathrm{d})$ than the other treatments. Intake rate increased when the amount of grass silage decreased, whereas meal duration decreased simultaneously. These effects were in line with a decreased DMI of the RGS diet vs. the other treatments, probably related to the high neutral detergent fiber (NDF) content. However,
\end{abstract}

Received May 12, 2008.

Accepted August 19, 2008.

${ }^{1}$ Corresponding author: Sander.Abrahamse@wur.nl this effect was not found in CSC, although NDF content of the TMR, fractional clearance rate of NDF, and fractional degradation rate of NDF was similar between CSC and RGS. Rumen fluid pH was lesser, and molar proportions of acetic acid and of propionic acid were lesser and greater, respectively, in RCS compared with all other diets. Milk production did not differ between treatments. There was no effect of type of concentrate on milk composition, but diet RCS resulted in a lesser milk fat content and greater milk protein content than diet RGS. Lactation stage did affect short-term feed intake behavior and DMI, although different grass silages were fed during early and late lactation. The results indicate that short-term feed intake behavior is related to DMI and therefore may be a helpful tool in optimizing DMI and milk production in high-production dairy cows.

Key words: dairy cow, feed intake behavior, rumen fermentation, milk yield

\section{INTRODUCTION}

In dairy cows, DMI is critical to achieve high milk production. In general, DMI does not meet the energy requirements for maintenance and production in highproductive early lactating animals. This results in a negative energy balance accompanied by an increase in the incidence of metabolic diseases and a reduction in reproductive performance (van Knegsel et al., 2005). A better understanding of factors affecting DMI provides opportunities to increase DMI and thereby milk production (Grant and Albright, 1995), potentially increasing profitability of dairy farming. The study of short-term feeding behavior may assist in understanding variation in daily DMI (Tolkamp et al., 2002). In particular, understanding of the factors limiting DMI due to short-term constraints (e.g., rumen fill) and rumen $\mathrm{pH}$ dynamics (resulting in subacute rumen acidosis, for example) are of relevance.

Cows eat in discrete meals alternated with periods of ruminating and idling (noneating behavior). These meals are separated by the meal criterion, which is the length of the longest interval still considered an inter- 
val within meals (Tolkamp et al., 1998). Hence, daily DMI can be described in terms of the number of meals per day, the length of meals, and the intake rate (IR) during meals (Dado and Allen, 1994). Manipulation of any of these variables may result in a change in DMI. This might be caused by several management factors including feeding space (DeVries et al., 2004), animal factors like lameness, and potentially also by the ration fed. A direct effect of the intake pattern on DMI could occur if, for example, a few large meals decreased rumen $\mathrm{pH}$ more severely than many small meals. Due to interference with rumen fermentation, this might affect the profile of supplied nutrients.

Much research was carried out on dietary factors affecting DMI. One of these factors is the type of silage fed to dairy cows. Deswysen et al. (1993) evaluated the effect of corn silage vs. grass silage on eating behavior in heifers and found that intake was greater with corn silage than with grass silage, associated with a shorter eating time and fewer meals, implicating a greater IR within meals with corn silage. Similar results on eating behavior were found by Dulphy et al. (1980) in sheep, although DMI in this experiment was less on corn silage than on grass silage. The short-term feed intake behavior results in these experiments are potentially related to the greater NDF and lesser starch content in grass silage in comparison to corn silage (Dulphy et al., 1980). Not only is fermentation rate of NDF in the rumen generally slower than fermentation rate of starch, also, particle size distribution in grass silage differs from that in corn silage, with a greater proportion of large particles in grass silage (Bruining et al., 1998). This results in less clearance of OM (through degradation and passage) of grass silage than of corn silage. In early to midlactating dairy cows, increasing NDF content in the diet corresponded to increased time spent eating at the expense of time spent ruminating (Beauchemin, 1991), although in this experiment, forage:concentrate ratio was not kept constant between treatments.

High-producing dairy cows are often fed concentrates to supply sufficient energy and nutrients to meet their requirement. Differences in concentrate chemical composition, similar to differences in roughage chemical composition, resulted in altered feed intake behavior, although the effects may be limited, because only small differences in particle size occur in pelleted concentrates. When feeding diets containing $75 \%$ basic TMR plus an additional $25 \%$ pelleted concentrate high in starch or high in NDF to 24 lactating dairy cows, Miron et al. (2004) found that the number of meals and total time spent eating per day were greater on the NDF-rich concentrate. The intake per meal and the rate at which cows consumed feed were greater in the treatment with high starch concentrate.
In most of the experiments evaluating the effect of lactation stage on DMI, the effect of lactation stage was confounded by changes in the diet (Kertz et al., 1991). When feeding the same diet throughout the lactation, dairy cows were found not to regulate feed intake accurately according to their requirements for maintenance and milk production (Coppock et al., 1974; Oldenbroek, 1984). Effects of lactation stage on short-term feed intake behavior are hardly studied. From early to peak lactation, DeVries et al. (2003) found an increase in meal duration and frequency, although the effects seemed to stabilize at the end of their study period (between 35 and 94 DIM). In contrast, Friggens et al. (1998) did not find an effect of lactation stage on shortterm feed intake behavior except for the time spent eating per day.

The objective of this experiment was therefore to evaluate the effect of different silages (grass and corn silage) and different concentrates (high in NDF or high in starch content) in TMR fed to dairy cows in early and late lactation on short-term feed intake, daily intake, rumen fermentation variables, and milk yield. We hypothesized that increasing the amount of structural carbohydrates (NDF) in the TMR at the expense of nonstructural carbohydrates would result in longer and larger meals, slower rate of fermentation of the feed in the rumen, thus resulting in a reduction of rumen fermentation of the TMR. We also hypothesized that inducing this difference through the composition of the concentrate, rather than through the silage fed, would result in smaller differences between treatments. No effect of lactation stage on intake behavior was expected.

\section{MATERIALS AND METHODS}

\section{Animals and Experimental Design}

Two $5 \times 5$ Latin square experiments were conducted to evaluate the effect of 5 treatments using 15 dairy cows during early (experiment 1: between February 20 and June 11, 2004) and late lactation (experiment 2: between August 27 and December 14, 2004). Both experiments were approved by the Institutional Animal Care and Use Committee of Wageningen University. Each period in the Latin square design lasted $3 \mathrm{wk}$, with the first $2 \mathrm{wk}$ for adaptation. The treatments were as follows: i) a basic TMR with (all on DM basis) $55 \%$ roughage (27.5\% corn silage and $27.5 \%$ grass silage) and $45 \%$ concentrate (a 50:50 mixture of a concentrate rich in structural carbohydrates and a concentrate rich in nonstructural carbohydrates; treatment $\mathbf{C O N}$ ), ii) a TMR with $55 \%$ corn silage and $45 \%$ of the concentrate mixture (treatment RCS), iii) a TMR with $55 \%$ grass 
Table 1. Ingredient composition of the concentrates used in the TMR and of the concentrate fed during milking in the milking parlor (concentrate MP)

\begin{tabular}{|c|c|c|c|}
\hline Ingredient ( $\%$ as fed) & $\begin{array}{c}\text { Concentrate rich } \\
\text { in nonstructural } \\
\text { carbohydrates }(\mathrm{g} / \mathrm{kg})\end{array}$ & $\begin{array}{c}\text { Concentrate rich } \\
\text { in structural } \\
\text { carbohydrates }(\mathrm{g} / \mathrm{kg})\end{array}$ & $\begin{array}{c}\text { Concentrate } \\
\text { MP (g/kg) }\end{array}$ \\
\hline Corn & 25.0 & - & - \\
\hline Barley & 11.8 & - & - \\
\hline Wheat & 10.0 & - & - \\
\hline Soy hulls & - & 15.0 & - \\
\hline Lupins $<33.5 \%$ CP & - & 15.0 & - \\
\hline $\begin{array}{l}\text { Palm kernel expeller } \\
<22 \% \text { crude fiber }\end{array}$ & - & 12.0 & - \\
\hline Corn gluten feed & - & - & 19.3 \\
\hline Coconut expeller & - & - & 2.5 \\
\hline Sunflower seed, extracted & - & - & 2.8 \\
\hline Rapeseed meal & 17.8 & 7.0 & 3.0 \\
\hline Soybean meal (Mervobest) & 6.2 & 4.5 & 17.8 \\
\hline Soybean meal solvent extracted & 5.3 & 5.1 & 38.0 \\
\hline Molasses & 7.5 & 7.5 & 5.0 \\
\hline Citrus pulp & 10.6 & 12.9 & - \\
\hline Beet pulp & 2.5 & 17.0 & - \\
\hline Vinasses & - & - & 7.0 \\
\hline Palm oil & 0.1 & 1.0 & - \\
\hline Fat, animal origin & - & - & 1.0 \\
\hline Limestone & 1.0 & 0.3 & 1.8 \\
\hline Sodium bicarbonate & 1.0 & 1.0 & - \\
\hline Mineral-vitamin mixture ${ }^{1}$ & 0.8 & 0.8 & 1.0 \\
\hline Sodium chloride & 0.2 & 0.2 & 0.6 \\
\hline Magnesium oxide & 0.2 & 0.2 & - \\
\hline Monocalcium phosphate & 0.1 & 0.7 & 0.2 \\
\hline
\end{tabular}

${ }^{1}$ Contained per kilogram of mix: $93 \mathrm{~g}$ of $\mathrm{Ca}, 400 \mathrm{~g}$ of $\mathrm{Mg}, 5 \mathrm{mg}$ of S, $4 \mathrm{~g}$ of $\mathrm{Cu}, 3.3 \mathrm{~g}$ of $\mathrm{Mg}, 322 \mathrm{mg}$ of I, 97 $\mathrm{mg}$ of $\mathrm{Co}, 80 \mathrm{mg}$ of Se, 2,600,000 IU of vitamin A, 580,000 IU of vitamin E (Premix 2033, PreMervo, Utrecht, the Netherlands).

silage and $45 \%$ of the concentrate mixture (treatment RGS), iv) a TMR with $55 \%$ of the roughage mixture and $45 \%$ of the concentrate rich in nonstructural carbohydrates (treatment CNS), and v) a TMR with 55\% of the roughage mixture and $45 \%$ of the concentrate rich in structural carbohydrates (treatment CSC). The proportion of feed ingredients in each of the diets was based on DM content of silages obtained before the start of the experiment. The ingredient composition of concentrates and the proportion of feed ingredients in the different treatments based on actual DM content during the experiments are presented in Tables 1 and
2. The chemical composition of the concentrate and silages is presented in Table 3.

The 15 Holstein-Friesian cows, of which 5 were previously fitted with a rumen cannula $(10 \mathrm{~cm}$ i.d.; Bar Diamond Inc., Parma, ID) in the dorsal sac, were grouped according to parity, DIM, milk yield during the previous lactation, and presence of a rumen cannula and were randomly assigned to the treatments. At the start of experiment 1 and 2 , cows (5 primiparous, 10 multiparous) were $61 \pm 5.9$ and $245 \pm 6.2 \mathrm{DIM}$ (values expressed as means $\pm \mathrm{SE}$ ), respectively. The same cows were used during both experiments, with 1 exception,

Table 2. Proportion of feed ingredients in each of the treatments during early lactation (experiment 1) and late lactation (experiment 2)

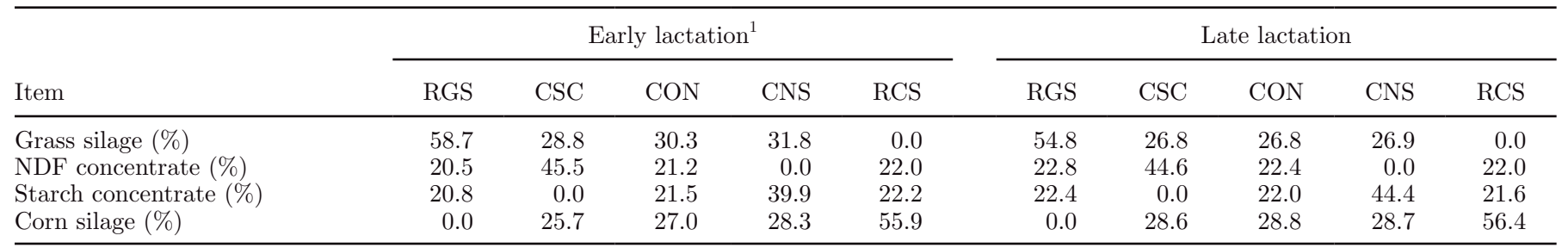

${ }^{1} \mathrm{RGS}=\mathrm{TMR}$ with $55 \%$ grass silage and $45 \%$ of the concentrate mixture; CSC $=$ TMR with $55 \%$ of the roughage mixture and $45 \%$ of the concentrate rich in structural carbohydrates; $\mathrm{CON}=\mathrm{TMR}$ with $55 \%$ of the roughage mixture and $45 \%$ of the concentrate mixture; $\mathrm{CNS}=\mathrm{TMR}$ with $55 \%$ of the roughage mixture and $45 \%$ of the concentrate rich in nonstructural carbohydrates; RCS $=$ TMR with $45 \%$ of the concentrate mixture and $55 \%$ corn silage. 
Table 3. Chemical composition of the silages and concentrates fed during early lactation (experiment 1) and late lactation (experiment 2) (g/ $\mathrm{kg}$ of DM unless otherwise stated)

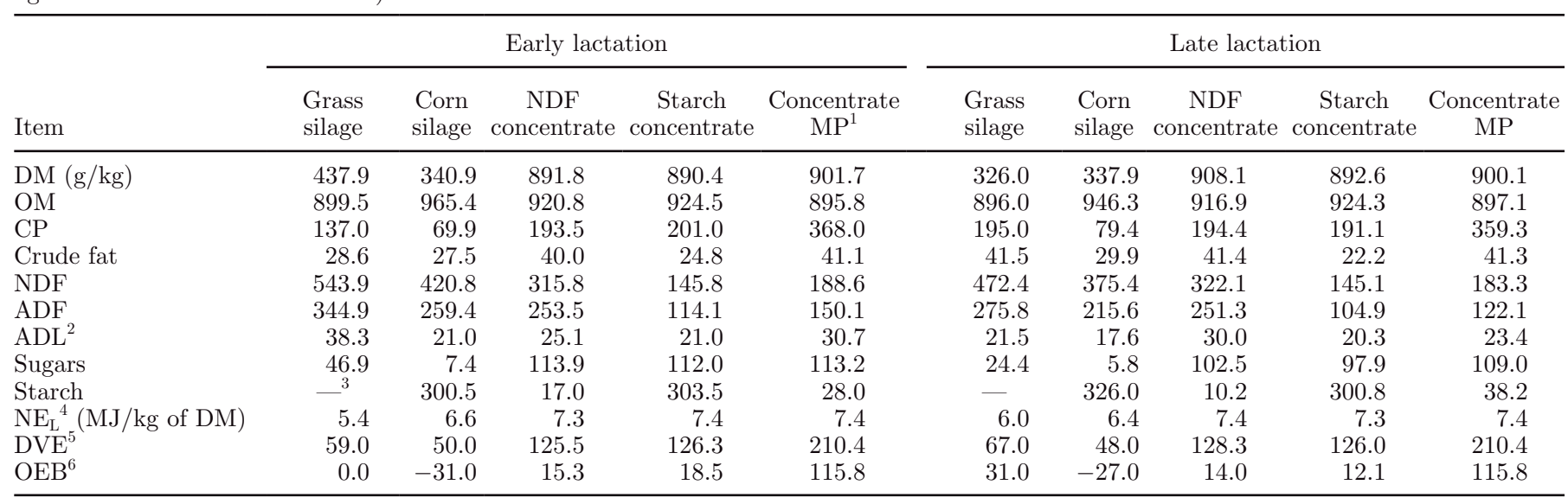

${ }^{1}$ Concentrate fed in the milking parlor.

${ }^{2}$ Acid detergent lignin.

${ }^{3}$ Not determined.

${ }^{4}$ Net energy for lactation calculated with VEM (feed unit lactation) system (Van Es, 1975).

${ }^{5}$ Intestinal digestible protein (Tamminga et al., 1994).

${ }^{6}$ Degraded protein balance (Tamminga et al., 1994).

because 1 cow was culled between experiments. This cow was replaced by a cow of equal parity and DIM in experiment 2. At the end of the second period of experiment 2 , data from 1 cow were excluded after repeated stealing feed from an incorrect treatment.

\section{Treatments and Feeding}

The cows were housed in a free-stall barn with an allowance of more than 1 cubicle per cow. The cubicles were bedded daily with sawdust on top of rubber mattresses. Individual eating behavior was continuously monitored throughout the study using feed bins (Nedap-Agri, Groenlo, the Netherlands) equipped with automated intake registration. Cows in each treatment had access to 2 feed bins. Weight changes of the bins $( \pm 0.1 \mathrm{~kg})$ were recorded, and time of start and end per visit was used to calculate intake and IR per visit. The bins were calibrated at the start of each period. Feed intake registration failed for 1 group during period 3 in experiment 1 (treatment RGS) and all groups during $2 \mathrm{~d}$ in period 2 in experiment 2 due to a registration problem with the computer, without affecting feed intake behavior. Water was available from 3 water troughs ad libitum.

The different TMR were mixed 3 times a week or more frequently if necessary to prevent storage problems caused by warm weather. After mixing, TMR were stored in a cooling unit at $4{ }^{\circ} \mathrm{C}$ and fed daily ad libitum ( $\pm 10 \%$ orts as fed) during morning milking. Cows were milked twice daily at 0730 and 1930 h. During each milking, all cows received $1 \mathrm{~kg}$ as fed of a protein-rich concentrate (Table 1) to prevent protein deficiency of cows fed the RCS treatment. The chemical composition of the TMR fed is presented in Table 4.

\section{Sampling and Analyses}

Feed Samples and Chemical Analyses. A representative sample of individual feedstuffs and of TMR was taken twice every period. The feedstuff samples were pooled per feedstuff per experiment, whereas the TMR samples were pooled per treatment per period. All samples were oven-dried for $24 \mathrm{~h}$ at $70^{\circ} \mathrm{C}$. Feed samples were ground to pass through a 1-mm sieve and analyzed for DM, inorganic matter (ash), CP, crude fat (CF), NDF, ADF, acid detergent lignin (ADL), and sugars as described by Abrahamse et al. (2008), and starch was analyzed using enzymatic hydrolysis (ISO 15914; ISO, 2004). Net energy for lactation was calculated using the feed unit lactation system (VEM; Van Es, 1975), and intestinal digestible protein (DVE) and degraded protein balance were calculated according to (Tamminga et al., 1994). Data used for these calculations were obtained from the concentrate supplier (concentrates) and near-infrared reflectance spectroscopy carried out by Blgg in Oosterbeek, the Netherlands (silages).

DMI and Feed Intake Behavior. After manually screening the DMI data to detect registration errors, visits to the feed bins were grouped into meals on the basis of the estimated meal criteria (i.e., the longest 
Table 4. Chemical composition of the different TMR fed during early lactation (experiment 1 ) and late lactation (experiment 2 ) (g/kg of DM unless otherwise stated)

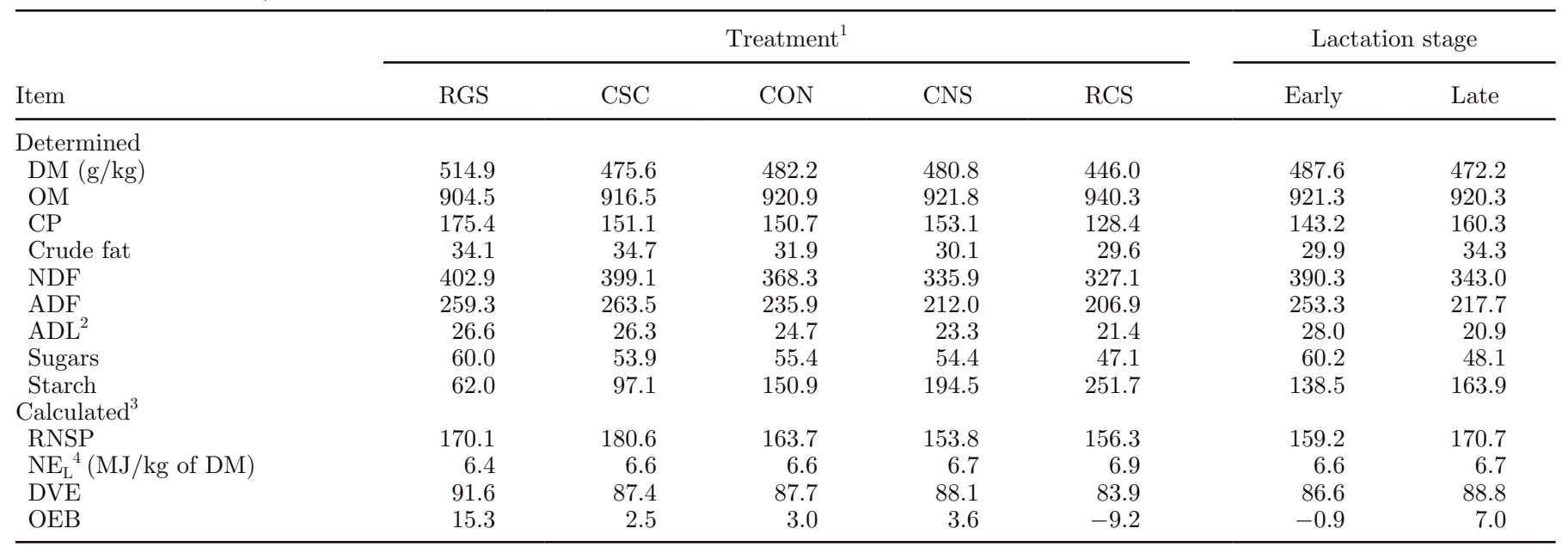

${ }^{1}$ RGS $=$ TMR with $55 \%$ grass silage and $45 \%$ of the concentrate mixture; CSC $=$ TMR with $55 \%$ of the roughage mixture and $45 \%$ of the concentrate rich in structural carbohydrates; $\mathrm{CON}=\mathrm{TMR}$ with $55 \%$ of the roughage mixture and $45 \%$ of the concentrate mixture; CNS $=$ TMR with $55 \%$ of the roughage mixture and $45 \%$ of the concentrate rich in nonstructural carbohydrates; RCS $=$ TMR with $45 \%$ of the concentrate mixture and $55 \%$ corn silage.

${ }^{2}$ Acid detergent lignin.

${ }^{3}$ Calculated values based on the ratio of different roughage and concentrate ingredients in the TMR and the data in Table 3 . RNSP(residual, nonstarch polysaccharides) is calculated as $\mathrm{OM}-\mathrm{CP}$ - crude fat - NDF - sugars - starch; $\mathrm{NE}_{\mathrm{L}}$ (in $\mathrm{MJ} / \mathrm{kg}$ of DM) is calculated with the VEM system (Van Es, 1975); DVE = intestinal digestible protein (Tamminga et al., 1994); OEB = degraded protein balance (Tamminga et al., 1994).

${ }^{4}$ Net energy for lactation calculated with VEM (feed unit lactation) system (Van Es, 1975).

interval not separating 2 meals). Meal criteria were estimated for each individual cow per dietary treatment during early and late lactation using the frequency distribution of log-transformed intervals between visits. A 3-population model was used, with 2 Gaussian distributions to describe within-meal intervals and a Weibull distribution to describe between-meal intervals (Tolkamp et al., 1998; Yeates et al., 2001). Eating time was calculated as meal duration minus intervals within meals. Some variables were analyzed per day as well as per meal (DMI, number of visits, eating time), whereas others were only analyzed per meal (IR, meal duration) or per day (number of meals).

Rumen Fluid. During the last day of each period, rumen fluid samples from the rumen-cannulated animals were taken after every visit to the feed bins between morning and evening milking. During the first $2 \mathrm{~h}$ after each visit, rumen fluid was sampled every 15 min, thereafter every $30 \mathrm{~min}$. Sampling was performed by taking equal amounts from the front and middle of the ventral sac and from the cranial sac, using a solid, perforated plastic tube $(85 \mathrm{~cm}$ long; $2.5 \mathrm{~cm}$ in diameter). Rumen $\mathrm{pH}$ was measured immediately after sampling using an electronic $\mathrm{pH}$ meter $(\mathrm{pH}$ electrode HI 1230, Hanna Instruments B.V., IJsselstein, the Netherlands). Time below $\mathrm{pH} 5.8$, indicative of rumen acidosis (Kolver and de Veth, 2002), was calculated as the sum of the time $\mathrm{pH}$ was below 5.8 per cow per day (min), assuming a linear increase or decrease between 2 consecutive samplings per cow. After rumen $\mathrm{pH}$ measurement, 2 subsamples of rumen fluid were taken, acidified with phosphoric acid or TCA, and stored at $-20^{\circ} \mathrm{C}$ pending VFA and $\mathrm{NH}_{3}-\mathrm{N}$ analyses, respectively, as described by Taweel et al. (2005).

Rumen Evacuations. The fistulated cows were deprived from feed for $12 \mathrm{~h}$ after the evening milking on the last day of each period. Rumen evacuations were carried out before and after fasting to determine rumen pool sizes and to calculate the fractional clearance rate (Kcl). The cows were brought to a tie-stall where rumen evacuations were carried out using the methodology described by Taweel et al. (2004), with 1 modification. The contents of the $10 \%$ sample fraction were squeezed through cheesecloth, and from the remaining solid material, a representative sample was taken. The original rumen contents were reconstituted by adding rumen fluid proportional to the weight of the squeezed solid and fluid. Rumen pool sizes of the different components (DM, OM, NDF, ADL, and CP) were calculated as the product of the total DM weight of the rumen content, and the content of each of the components at both evacuations. Rumen pool sizes before fasting were used for statistical analyses on rumen pool sizes, whereas values of both evacuations were used to calculate $\mathrm{Kcl}$ based on the assumption of first-order kinetics using the equation $\mathrm{RP}_{(\mathrm{t})}=\mathrm{RP}_{(0)} \times \mathrm{e}^{-\mathrm{Kcl} \times \mathrm{t}}$, where $\mathrm{RP}_{(0)}$ and 
$\mathrm{RP}_{(\mathrm{t})}=$ the rumen pool sizes $(\mathrm{kg})$ immediately before and after overnight fasting, respectively, and $\mathrm{t}=$ the time (h) between both evacuations.

In Situ Incubations. To evaluate rumen degradation of OM, N, NDF, and starch, in situ rumen incubations were carried out in a separate experiment between February 10 and March 12, 2005, using 5 nonlactating Holstein-Friesian cows and 1 cow in early lactation. One of the nonlactating cows delivered $4 \mathrm{~d}$ before the end of the incubations. Before the start of the in situ rumen incubations, cows were adapted during 2 wk to the CON treatment. Incubations were performed according to the all-out method described by Tas et al. (2006) with some modifications. Only concentrate and silage samples of experiment 2 were incubated in the rumen. Pelleted concentrates were ground to pass a 3-mm screen (type ZM 100, Retsch, Haan, Germany), whereas grass and corn silage samples were cut with a paper cutter at a length of 0.5 to $1 \mathrm{~cm}$ before incubations. Polyamide bags $(8.5 \times 16.5 \mathrm{~cm}$; pore size $40 \mu \mathrm{m}$; PA 40/30, Nybolt, Zurich, Switzerland) were filled with approximately $5 \mathrm{~g}$ of $\mathrm{DM}$ and incubated for $2,4,8,12$, 48, 72, and $336 \mathrm{~h}$. Bags for the short-term incubations ( 2 to $48 \mathrm{~h}$ ) were randomly distributed over 3 cows, whereas bags for the long-term incubations $(336 \mathrm{~h})$ were randomly distributed over the other 3 cows (including both lactating cows). After incubations, bags were immediately placed in ice water to stop fermentation and later rinsed with tap water. All bags were washed in a washing machine during $45 \mathrm{~min}$ with $55 \mathrm{~L}$ of cold water without centrifuging. After freeze-drying, residues of silages were ground to pass a 1-mm screen (type ZM 100, Retsch), and all residues were pooled per feed per incubation time and analyzed for DM, ash, N, NDF, and starch as described above. Data were fitted to the nonlinear first-order model of Robinson et al. (1986) using the PROC NLIN procedure of SAS (version 9.1, SAS Institute Inc., Cary, NC), and the effective degradability (ED) was calculated according to Tas et al. (2006) assuming a fractional passage rate of $0.045 / \mathrm{h}$ for silages and $0.060 / \mathrm{h}$ for concentrates (Tamminga et al., 1994). Effective degradability of each TMR was calculated from the ED of the individual feeds, corrected for the contents of each of the chemical components.

Milk Yield and Composition. Individual milk yield was recorded throughout the experiment. During the last $2 \mathrm{~d}$ of each measurement period, milk samples were taken during 4 consecutive milkings per cow and stored and analyzed for fat, protein, lactose, and urea content as described by Abrahamse et al. (2008). The fat- and protein-corrected milk (FPCM, $\mathrm{kg} / \mathrm{d})$ was calculated as: $[0.337+0.116 \times$ fat $(\%)+0.06 \times$ protein $(\%)] \times$ milk yield $(\mathrm{kg} / \mathrm{d})$.

\section{Statistical Analyses}

The effect of lactation stage was confounded with the effect of different grass and corn silages used in experiment 1 and 2 . In the description of statistical analyses, this is taken together as the effect of lactation stage. Results are presented as means with their SEM. Amount of FPCM, content of milk components, and rumen variables were averaged per cow per period. Consequently, data were analyzed as a replicated $5 \times$ 5 Latin square using the MIXED procedure of SAS (version 9.1, SAS Institute Inc.) with model effects for treatment, lactation stage, and period and the random effect of cow. A similar model was run for meal criterion data, with the exception that cow was a fixed effect. The interaction between treatment and lactation stage was included in the model for meal criteria and milk components, but it was excluded from the model for all other variables due to lack of significance $(P>0.05)$. The number of meals, eating time, DMI, and milk yield of each cow were calculated per day. Consequently, data were analyzed as a replicated $5 \times 5$ Latin square with model effects for treatment, lactation stage, period, day, and the interaction between lactation stage and treatment as fixed effects and cow as random effect, using the MIXED procedure of SAS. Day was used as a REPEATED model statement (Littell et al., 1998) with a first-order autoregressive covariance structure [AR(1)] (Tempelman, 2004). Differences were considered significant at a probability of $P<0.05$, and posthoc analyses were carried out using the Tukey test to test pairwise comparisons.

\section{RESULTS}

\section{Chemical Composition of TMR}

Formulation of the different TMR resulted in an expected decrease in NDF and increase in starch and sugar content between treatments that differed in silage component (order RGS - CON - RCS) and in concentrate component (order CSC - CON - CNS; Table 4). In addition, due to the lesser $\mathrm{CP}$ and $\mathrm{CF}$ content of the corn silage than the grass silage, CP and $\mathrm{CF}$ decreased in the order RGS - CON - RCS. The decrease in CP resulted in a decrease in DVE and degraded protein balance between treatments differing in silage components.

\section{DMI and Feed Intake Behavior}

Meal criteria differed between lactation stages, but there was no effect of cow, treatment, and period $(P>$ 0.05; Table 5). A significant interaction between treat- 
ment and lactation stage $(P=0.024)$ was found, caused by a greater meal criterion in early lactation than in late lactation for CSC and CNS. Due to the interaction between treatment and lactation stage, individual meal criteria per treatment for both experiments were used to calculate meals.

The DMI was lesser $(P<0.001)$ in RGS compared with the other treatments, and DMI was slightly lesser $(P=0.017)$ in late lactation than in early lactation (Table 5). The calculated energy balance (using the Dutch feed evaluation system for energy; Van Es, 1975) was positive for each treatment in both lactation stages. There were differences between treatments, with a more positive energy balance in RCS than in RGS (23.7 vs. $4.9 \mathrm{NE}_{\mathrm{L}} / \mathrm{d}$ ) and a more positive energy balance in late lactation than in early lactation (30.8 vs. $1.6 \mathrm{NE}_{\mathrm{L}} / \mathrm{d}$; results not shown). The number of meals was similar between treatments, whereas in late lactation, the number of meals was greater $(P<0.001)$ than in early lactation (7.7 and 7.2 meals per day, respectively; Table $5)$. Eating time in RGS $(227 \mathrm{~min} / \mathrm{d})$ was greater, and that in RCS $(177 \mathrm{~min} / \mathrm{d})$ was lesser $(P<0.05)$ than in all other treatments. Moreover, eating time in early lactation $(231 \mathrm{~min} / \mathrm{d})$ was greater $(P<0.001)$ than in late lactation $(178 \mathrm{~min} / \mathrm{d})$. However, an interaction between treatment and lactation stage was observed $(P$ $<0.001)$ in the number of meals and in eating time per day (Figure 1). In early lactation, the number of meals in RGS $(6.6 / \mathrm{d})$ was lesser $(P<0.001)$ than in RCS $(7.8 / \mathrm{d})$, whereas in late lactation, diet did not affect the number of meals. Dietary effects on eating time per day were also more pronounced in early lactation than in late lactation. In early lactation, eating time per day in RGS was greater $(P=0.002)$ and in CNS and RCS lesser $(P=0.002$ and $P<0.001$, respectively) than in $\mathrm{CON}$, whereas in late lactation, only eating time in CON was greater $(P<0.020)$ from that in CNS.

Within a meal, number of visits, eating time, and meal duration were all lesser $(P<0.001)$ and IR was greater $(P<0.001)$ in late lactation than in early lactation. The number of visits per meal, eating time per meal (the net time spent eating during meals), and meal duration (the total time spent on eating behavior, including within-meal intervals) differed between treatments $(P<0.05)$. Intake rate per meal showed the largest differences between treatments with a greater IR in RCS and CNS $(P<0.01)$ than in the other diets and a greater IR in CON and CSC $(P<0.001)$ than in RGS.

The interaction between treatment and lactation stage was significant for all intake variables per meal. The number of visits per meal was lesser in RCS in early lactation than in CNS and CON $(P<0.005)$, whereas in late lactation, it was similar between treat-

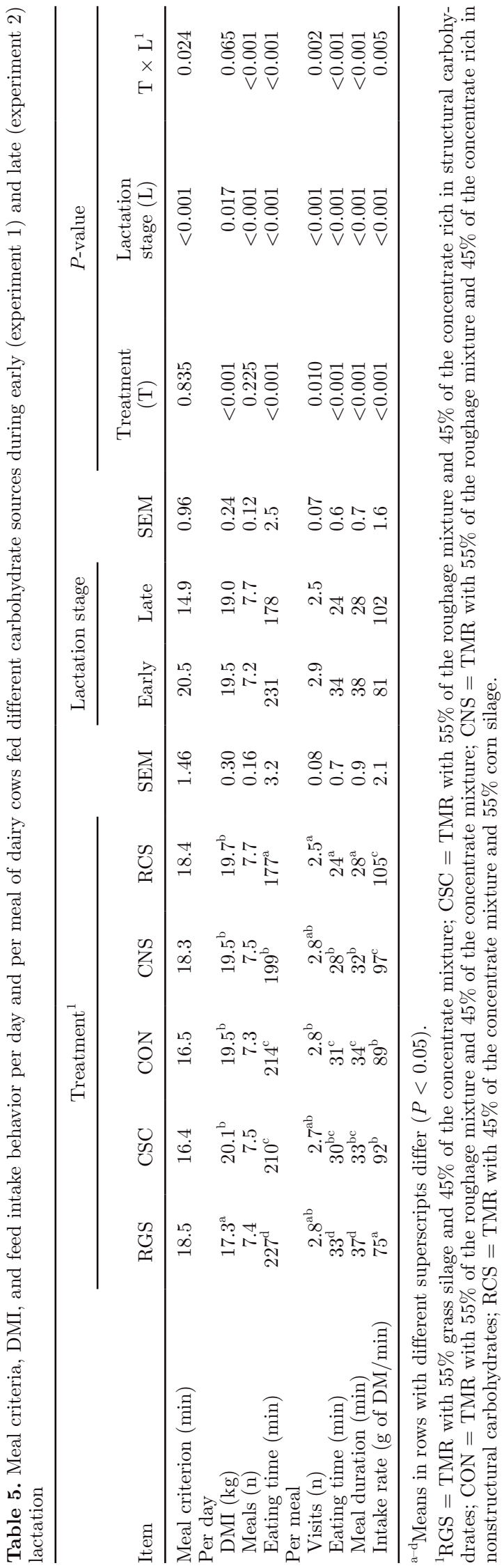



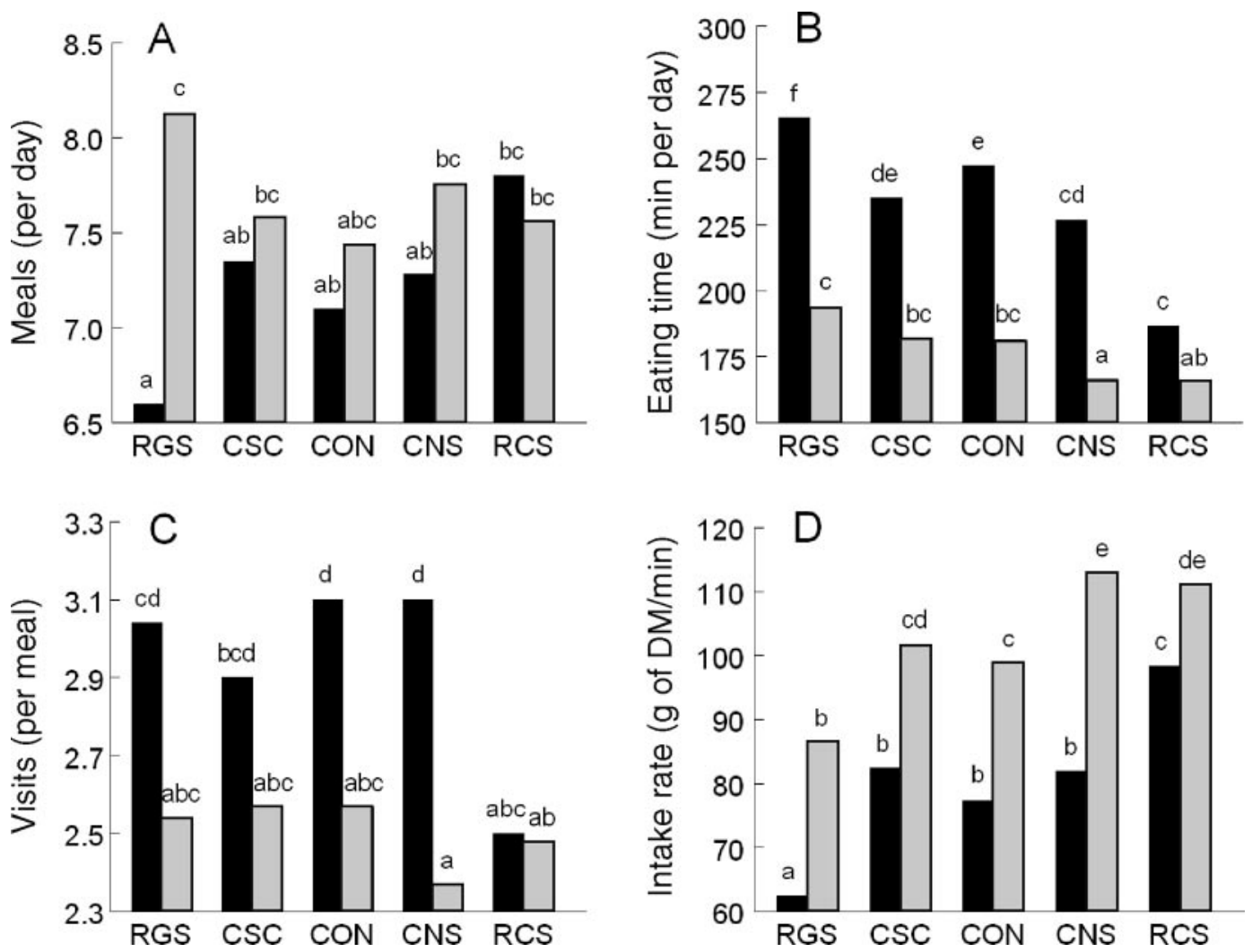

Figure 1. (A) Number of meals and (B) eating time per day, and (C) number of visits and (D) intake rate per meal of dairy cows fed different carbohydrate sources during early (black bar) and late (gray bar) lactation. Means with different letters differ within the variable tested $(P<0.05)$. RGS $=$ TMR with $55 \%$ grass silage and $45 \%$ of the concentrate mixture; CSC $=$ TMR with $55 \%$ of the roughage mixture and $45 \%$ of the concentrate rich in structural carbohydrates; CON $=$ TMR with $55 \%$ of the roughage mixture and $45 \%$ of the concentrate mixture; CNS $=\mathrm{TMR}$ with $55 \%$ of the roughage mixture and $45 \%$ of the concentrate rich in nonstructural carbohydrates; RCS $=$ TMR with $45 \%$ of the concentrate mixture and $55 \%$ corn silage.

ments. Eating time and meal duration per meal were longer in RGS in early lactation than in CNS, CSC, and CON $(P<0.001)$, whereas in RCS, it was shortest $(P<0.001)$, although in late lactation, it only differed between CON and CNS $(P=0.047$; not shown in Figure 1). The differences in IR between diets were rather similar in early compared with late lactation. However, in late lactation, IR per meal in CNS was greater $(P<$ $0.05)$ than in CON, CSC, and RGS, whereas in early lactation, IR per meal in CNS was only greater than in RGS $(P<0.001)$ and lesser than in RCS $(P<0.001$; Figure 1).

Although investigation of the effects of parity on DMI and milk production was not part of the objectives of this article, short-term feed intake behavior differed $(P$ $<0.05$ ) between primiparous and multiparous cows. In comparison to primiparous cows, multiparous cows had a greater DMI and number of meals per day, and eating time per meal was lesser, although IR was not increased as compared with primiparous cows. This resulted in a greater milk production per day in multiparous cows than in primiparous cows, although other milk variables were similar between different parities (data not shown).

\section{Rumen Variables}

The effect of treatment and lactation stage on rumen $\mathrm{pH}, \mathrm{VFA}$ concentration, $\mathrm{NH}_{3}-\mathrm{N}$, and molar proportions of different VFA is presented in Table 6. In general, rumen variables from cows fed the RCS diet differed from the other treatments, with small differences between the latter diets. Rumen $\mathrm{pH}$ was lesser $(P<0.05)$, and the duration of ruminal $\mathrm{pH}<5.8$ was longer $(P<0.01)$ for RCS than the other diets. The nonglucogenic:glucogenic VFA ratio was lesser for RCS $(P<0.05)$, mainly due to the lesser molar proportion of acetate $(P<0.01)$, and greater molar proportions of propionate $(P<0.05)$ and valerate $(P<0.05)$. Rumen $\mathrm{NH}_{3}-\mathrm{N}$ concentrations decreased when grass silage was replaced with corn 
silage with no effect of concentrate type. Late-lactating animals had a lesser $\mathrm{pH}(P=0.022)$ than early lactating animals, but the duration of ruminal $\mathrm{pH}<5.8$ did not differ between early and late lactation. Total VFA $(P<0.001)$ and $\mathrm{NH}_{3}-\mathrm{N}$ concentration $(P<0.001)$ were greater in late lactation, but VFA molar proportions did not differ, except for lesser isobutyrate proportions in late lactation than in early lactation $(P=0.029)$.

Prefasting rumen pool sizes differed $(P<0.05)$ between treatments, except the pool size of NDF and OM (Table 7). Rumen fractional clearance rates were similar between treatments, except for the rumen $\mathrm{Kcl}$ of NDF that was lesser in RCS than in RGS and CSC. Rumen pool sizes were lesser $(P<0.01)$, and fractional clearance rates were greater $(P<0.05)$ in late lactation as compared with early lactation.

Estimates of degradation characteristics of silages and concentrates fed during experiment 2 are presented in Table 8. Effective degradability of $\mathrm{N}$ and NDF of the different treatments decreased, whereas the ED of starch increased and the ED of OM (ED $\left.\mathbf{E M}_{\mathrm{OM}}\right)$ was similar when concentrations of corn silage in the TMR increased. Similar results were found with increasing concentrations of starch concentrate, although the ED of starch decreased and $\mathrm{ED}_{\mathrm{OM}}$ increased slightly. Also, the differences were smaller than when silage components were changed in the TMR.

\section{Milk Production and Composition}

Milk and FPCM yield were similar between treatments (Table 9). Fat content was lesser in RCS than in RGS, CSC, and CON $(P<0.05)$. The effect of dietary treatment on milk protein content was dependent of lactation stage (treatment $\times$ lactation stage interaction, $P=0.012)$. In early lactation, protein content in RCS was greater than in RGS $(P<0.001)$, whereas type of carbohydrate in the concentrate had no effect. In late lactation, milk protein content was similar between treatments. Milk and FPCM production was greater in early lactation than in late lactation $(P<$ $0.001)$. In early lactation, milk fat $(P<0.001)$ and milk protein content $(P<0.001)$ was lesser and milk lactose content greater $(P<0.001)$ than in late lactation. Milk urea was also lesser $(P<0.001)$ in early than in late lactation.

\section{DISCUSSION}

\section{Meal Criteria Estimation}

In recent literature on feed intake behavior in dairy cows, the intake pattern is separated into bouts or meals, based on frequency distributions of interval

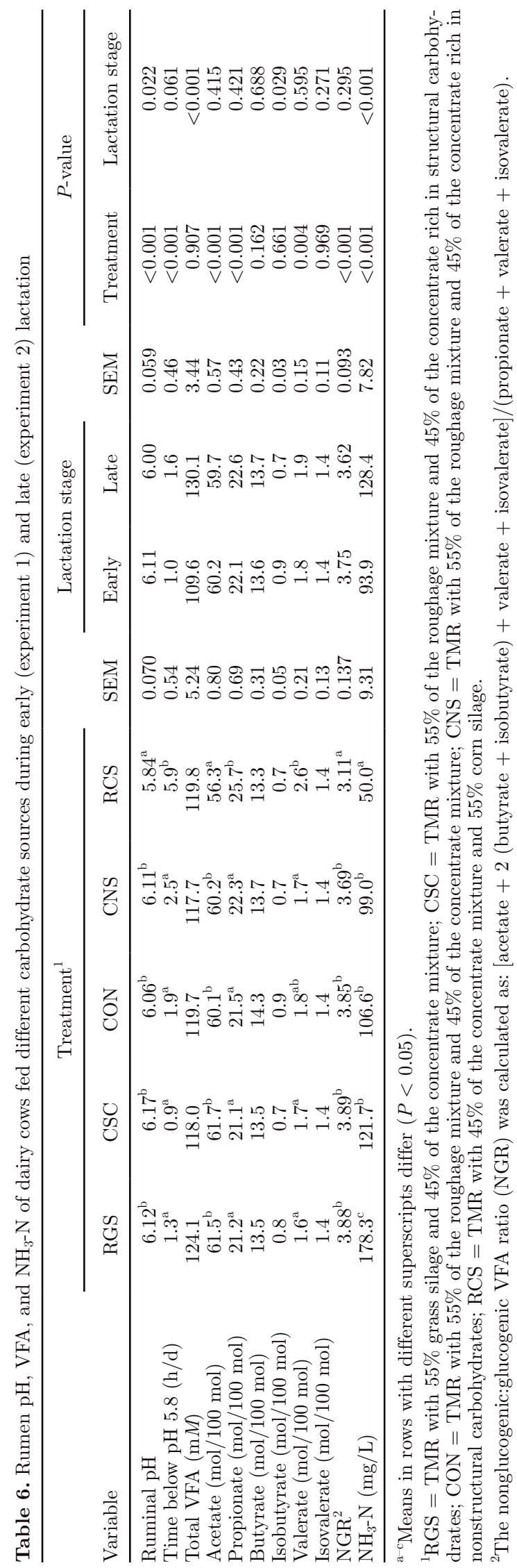


Table 7. Rumen pool sizes immediately before fasting and their fractional clearance rates of dairy cows fed different carbohydrate sources during early (experiment 1) and late (experiment 2) lactation

\begin{tabular}{|c|c|c|c|c|c|c|c|c|c|c|c|}
\hline \multirow[b]{2}{*}{ Variable $^{2}$} & \multicolumn{5}{|c|}{ Treatment $^{1}$} & \multirow[b]{2}{*}{ SEM } & \multicolumn{2}{|c|}{ Lactation stage } & \multirow[b]{2}{*}{ SEM } & \multicolumn{2}{|c|}{$P$-value } \\
\hline & RGS & $\mathrm{CSC}$ & $\mathrm{CON}$ & CNS & RCS & & Early & Late & & Treatment & Lactation stage \\
\hline RDM (kg) & $17.0^{\mathrm{ab}}$ & $17.9^{\mathrm{b}}$ & $16.7^{\mathrm{ab}}$ & $16.1^{\mathrm{ab}}$ & $14.5^{\mathrm{a}}$ & 1.42 & 18.5 & 14.7 & 1.31 & 0.035 & $<0.001$ \\
\hline $\mathrm{RCP}(\mathrm{kg})$ & $3.7^{\mathrm{c}}$ & $3.4^{\mathrm{bc}}$ & $3.2^{\mathrm{bc}}$ & $3.0^{\mathrm{b}}$ & $2.3^{\mathrm{a}}$ & 0.28 & 3.4 & 2.9 & 0.26 & $<0.001$ & 0.001 \\
\hline RNDF (kg) & 8.0 & 9.2 & 8.6 & 8.4 & 8.3 & 0.75 & 9.9 & 7.2 & 0.70 & 0.163 & $<0.001$ \\
\hline RADL (kg) & $0.8^{\mathrm{ab}}$ & $0.9^{\mathrm{b}}$ & $0.8^{\mathrm{ab}}$ & $0.8^{\mathrm{ab}}$ & $0.7^{\mathrm{a}}$ & 0.08 & 0.9 & 0.7 & 0.07 & 0.025 & $<0.001$ \\
\hline $\operatorname{Kcl}_{\mathrm{CP}}\left(\mathrm{h}^{-1}\right)$ & 5.2 & 5.8 & 5.2 & 5.4 & 5.9 & 0.42 & 5.0 & 5.9 & 0.35 & 0.387 & 0.003 \\
\hline $\operatorname{Kcl}_{\mathrm{NDF}}\left(\mathrm{h}^{-1}\right)$ & $5.0^{\mathrm{b}}$ & $5.1^{\mathrm{b}}$ & $4.7^{\mathrm{ab}}$ & $4.4^{\mathrm{ab}}$ & $3.9^{\mathrm{a}}$ & 0.45 & 3.9 & 5.3 & 0.42 & 0.002 & $<0.001$ \\
\hline $\operatorname{Kcl}_{\mathrm{ADL}}\left(\mathrm{h}^{-1}\right)$ & 3.6 & 4.1 & 3.6 & 3.3 & 3.5 & 0.42 & 3.2 & 4.0 & 0.38 & 0.093 & $<0.001$ \\
\hline
\end{tabular}

${ }^{\mathrm{a}-\mathrm{c}}$ Means in rows with different superscripts differ $(P<0.05)$.

${ }^{1} \mathrm{RGS}=\mathrm{TMR}$ with $55 \%$ grass silage and $45 \%$ of the concentrate mixture; CSC $=$ TMR with $55 \%$ of the roughage mixture and $45 \%$ of the concentrate rich in structural carbohydrates; $\mathrm{CON}=\mathrm{TMR}$ with $55 \%$ of the roughage mixture and $45 \%$ of the concentrate mixture; CNS $=\mathrm{TMR}$ with $55 \%$ of the roughage mixture and $45 \%$ of the concentrate rich in nonstructural carbohydrates; RCS $=$ TMR with $45 \%$ of the concentrate mixture and $55 \%$ corn silage.

${ }^{2} \mathrm{RDM}=$ rumen $\mathrm{DM}$ content; $\mathrm{ROM}=$ rumen $\mathrm{OM}$ content; $\mathrm{RCP}=$ rumen $\mathrm{CP}$ content; $\mathrm{RNDF}=$ rumen NDF content; RADL $=$ rumen acid detergent lignin $(\mathrm{ADL})$ content; $\mathrm{Kcl}_{\mathrm{DM}}=$ fractional clearance rate of $\mathrm{DM} ; \mathrm{Kcl}_{\mathrm{OM}}=$ fractional clearance rate of $\mathrm{OM} ; \mathrm{Kcl}_{\mathrm{CP}}=\mathrm{fractional}_{\mathrm{clearance}}$ rate of $\mathrm{CP} ; \mathrm{Kcl}_{\mathrm{NDF}}=$ fractional clearance rate of $\mathrm{NDF} ; \mathrm{Kcl}_{\mathrm{ADL}}=$ fractional clearance rate of $\mathrm{ADL}$.

lengths between feeding events. From such distributions, the meal criterion is estimated using log transformations (Tolkamp et al., 1998; Yeates et al., 2001). The log-transformed intervals between visits to feeding bins used in these models are in better agreement with the satiety concept, implying that the initiation of a meal is not independent of the time since the last meal (Tolkamp and Kyriazakis, 1999).

When estimating the meal criteria, several factors need to be considered. The first choice is that of the model to fit the data. Estimation of meal criteria is done both with 2-population models [Gaussian-Gaussian (DeVries et al., 2003; Huzzey et al., 2005) and Gaussian-Weibull (Melin et al., 2005)] and 3-population models [GaussianGaussian-Weibull, GGW; Yeates et al. (2001); Melin et al. (2005)]. The choice between the different models in the current experiment was carried out according to Melin et al. (2005), using the minimum function value described by (Yeates et al., 2001). In agreement with results reported by Yeates et al. (2001) and Melin et al. (2005), the GGW model was found to fit the data best. Indeed, Weibull distributions are believed to be in better agreement with the satiety concept, because the probability of cows initiating a new meal is expected to increase with time since the last meal (Yeates et al., 2001).

The second choice is to decide which meal criteria to use for grouping visits to the feeding bins into meals. Because in the present study, significant effects of lactation stage and treatment $\times$ lactation stage interactions occurred, meal criteria per treatment-lactation stage combination were used to pool intake data. No consis- tent effect of treatment on meal criteria estimation was found, similar to findings of Tolkamp et al. (2002), who tested if the ratio of concentrate to grass silage influenced meal patterns in dairy cows. Also, Melin et al. (2005) found no differences in estimated meal criteria between cows milked 3 times daily vs. 6 times daily, when using the GGW model.

In our study, the effect of cow on meal criterion was not significant. DeVries et al. (2003) found no differences in intake behavior variables when a meal criterion was used estimated from intake data from all animals within periods or estimated from intake data per animal per period and hence used 1 meal criterion based on pooled data. However, Huzzey et al. (2005) found differences between these 2 methods and used meal criteria for individual cows. To test with a similar approach if the statistical method applied in this experiment resulted in satisfactory results, the meal criterion estimated using data of all animals per treatment-lactation stage combination (pooled data, $\mathrm{M}_{\mathrm{p}}$ ) or using individual animal data $\left(\mathrm{M}_{\mathrm{i}}\right)$ was used to calculate the number of meals per treatment. Both meal criteria resulted in similar numbers of meals per treatment $\left[\mathrm{M}_{\mathrm{i}}\right.$ $\left.=0.95( \pm 0.02) \times \mathrm{M}_{\mathrm{p}}+0.27( \pm 0.13) ; \mathrm{r}^{2}=0.85\right]$, al though in the current experiment, in line with Huzzey et al. (2005), a significant relationship between meals calculated based on individual or based on combined meal criteria was observed; Huzzey et al. (2005) found a consistent deviation between both meal frequencies in the postcalving period. Thus, a significant relationship does not guarantee that the various short-term intake variables do not differ between both meal criteria esti- 
Table 8. Estimates of OM, N, NDF, and starch degradation characteristics of the different silages and concentrates used during late lactation

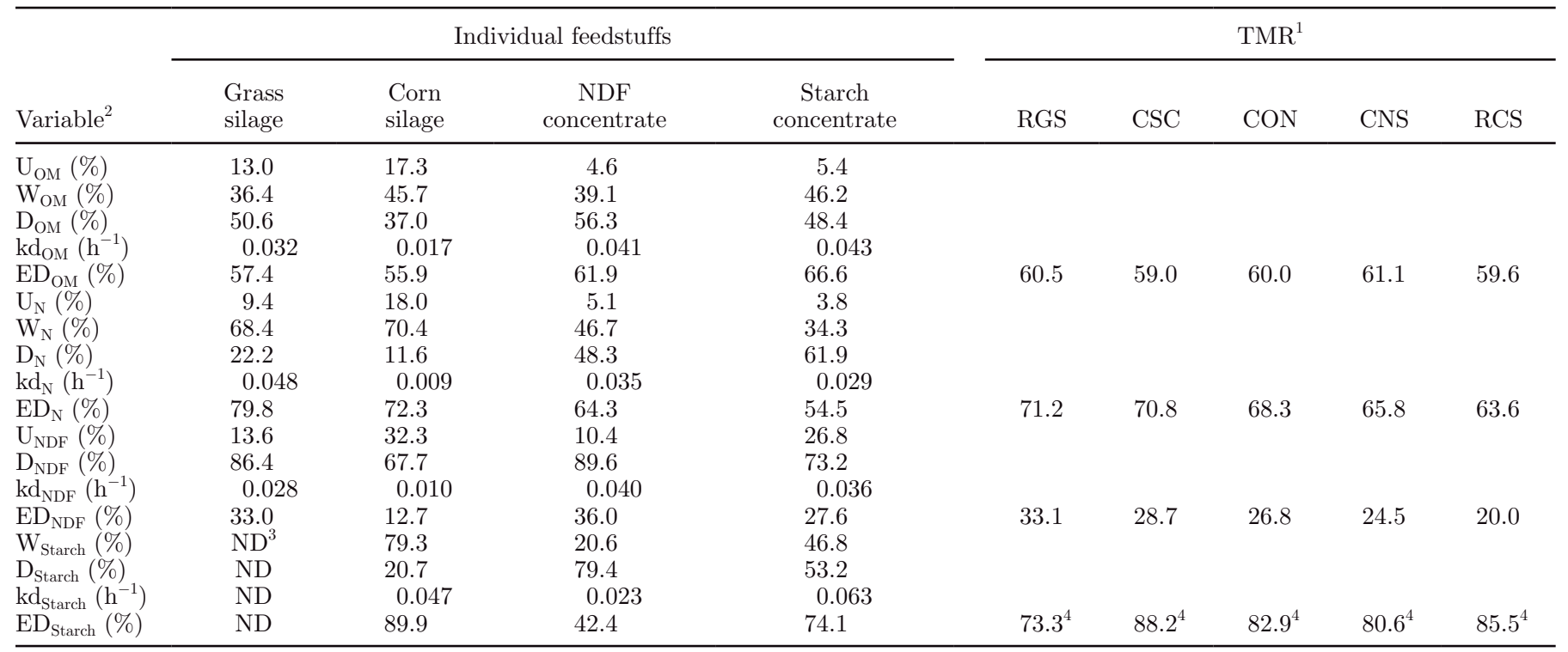

${ }^{1} \mathrm{RGS}=\mathrm{TMR}$ with $55 \%$ grass silage and $45 \%$ of the concentrate mixture; CSC $=$ TMR with $55 \%$ of the roughage mixture and $45 \%$ of the concentrate rich in structural carbohydrates; $\mathrm{CON}=\mathrm{TMR}$ with $55 \%$ of the roughage mixture and $45 \%$ of the concentrate mixture; $\mathrm{CNS}=\mathrm{TMR}$ with $55 \%$ of the roughage mixture and $45 \%$ of the concentrate rich in nonstructural carbohydrates; RCS $=$ TMR with $45 \%$ of the concentrate mixture and $55 \%$ corn silage.

${ }^{2} \mathrm{U}=$ undegradable fraction; $\mathrm{W}=$ washable fraction; $\mathrm{D}=$ potential degradable fraction; $\mathrm{kd}=$ fractional degradation rate; ED = effective degradability $\left[\mathrm{ED}=\mathrm{W}+\mathrm{kd} /\left(\mathrm{kd}+\mathrm{k}_{\mathrm{p}}\right) \times \mathrm{D}\right]$, where $\mathrm{k}_{\mathrm{p}}$ was assumed $0.045 / \mathrm{h}$ for silages and $0.060 / \mathrm{h}$ for concentrates (Tamminga et al., 1994). Effective degradability of TMR was calculated from the ED of individual feedstuffs, corrected for the concentration of each chemical component.

${ }^{3}$ Not determined.

${ }^{4}$ Assuming starch content of grass silage is zero.

mation methods This is another reason to rather use a statistical test to determine effects on the meal criteria estimation and decide which meal criteria to use to calculate feed intake variables. The present statistical test enables the estimation of meal criteria based on the contribution of various sources of variation (animal, treatment, lactation stage).

\section{Lactation Stage and Different Silages}

In contrast to our hypothesis, lactation stage significantly affected several feed intake behavior variables. When comparing both experiments described in the present study, the effect of lactation stage is confounded with the use of different silages and concentrate batches in early and in late lactation. Such confounding effects occur regularly when testing lactation stage effects (e.g., Kertz et al., 1991). Confounding effects of the animals used were limited, because all cows except one were used in early and in late lactation. Because the composition of the grass silage differed to a much larger extent than that of concentrates or corn silage (Table 3), potential confounding effects between lactation stage and feeds between experiments are expected to be caused mainly by grass silage. Storage of silage used in early lactation to be used also in later lactation was not feasible due to practical constraints at the research farm. However, even within silages over time, during storage of corn silage, the degradability of starch increases (Newbold et al., 2006), indicating that storage of silages between experiments would not have ensured similar availabilities of nutrients to the animals. Treatment RGS (with grass silage as the largest component of the diet) indeed showed the greatest differences between early and late lactation in eating time and number of meals (Figure 1). Moreover, the interaction between treatment and lactation stage in visits per meal and IR per meal indicates a disturbing effect of grass silage between early and late lactation.

There was a tendency for an interaction between treatment and lactation stage in DMI per day. Intake was lesser in RGS than in all other treatments in early and late lactation, but the numerical difference between RGS and the other treatments was smaller in late lactation than in early lactation $(2.0$ vs. $2.7 \mathrm{~kg} / \mathrm{d}$, respectively). This larger difference in intake between RGS and the other treatments in early lactation coincided with greater DM, NDF, and ADL contents of grass silage in early compared with late lactation. Indeed, $\mathrm{DMI}$ is expected to be lesser when silages are greater in 
NDF (Allen, 2000). In addition, a greater ADL content of silage decreases the digestibility of the diet, decreasing fractional passage rate and DMI through effects on rumen fill (Jung and Allen, 1995).

Even under the hypothesis that grass silage did influence the experimental results, from Figure 1 it is clear that there were also differences in feed intake behavior due to lactation stage. Lactation stage significantly affected all intake variables studied (Table 5), even for the diet without any grass silage (diet RCSl Figure 1). Such effects of lactation stage on feed intake behavior have only been investigated to a limited extent. Friggens et al. (1998), when studying feed intake on a complete lactation in 20 cows, found a gradual decrease in DMI as the lactation progressed, after a steep increase at the start of the lactation. In line with the present results, the time spent eating was decreased with lactation stage. In contrast, DeVries et al. (2003) found an increase in time spent eating, only between period 1 (35 DIM) and period 2 (57 DIM) but not in periods after peak lactation. Moreover, in line with our results, DeVries et al. (2003) observed a greater number of meals per day in late-lactating cattle than in early lactating cattle.

To investigate the net effect of feed intake behavior without confounding effects of nutrient composition, digestibility, and particle size of the diet, it would be necessary to impose a specific feed intake behavior regime on animals fed similar diets. An attempt to do so could be carried out using automatic feed bins allowing cows to eat only during certain times combined with registration of the actual intake and time.

\section{Feed Intake Behavior in Different Treatments}

Effects of NDF and starch in the diet on short-term feed intake behavior in ruminants have been studied before (Abijaoudé et al., 2000; Allen, 2000; Miron et al., 2004). However, a comparison of such effects upon changing the type of silage or the type of concentrate using the same concentrate:silage ratio within a single experiment has to our knowledge not been reported. In line with our hypothesis, the present results indicate that changing the composition of silage in the TMR has a larger effect on short-term feed intake behavior than changing the concentrate composition (Table 5). This may be related to the larger differences in NDF and starch content of the TMR between RGS and RCS than between CSC and CNS (Table 4), as well as to the differences in particle size between both silages (Allen, 2000) that are not apparent in the pelleted concentrates.

Although effects of forage cell-wall constituents on voluntary DMI have been frequently studied (e.g., Al- 
len, 2000), experimental evidence on their effects on short-term feed intake behavior is limited. Dado and Allen (1995) studied the effects of a low-fiber diet (NDF $25 \%$ of DM) vs. a high-fiber diet (NDF $35 \%$ of DM) and found that eating time and ruminating time were increased in the latter treatment. However, in their experiment, the concentrate:forage ratio differed between treatments. Dulphy et al. (1980) reviewed effects of fresh cut forage cell-wall constituents on feeding behavior of wethers. Greater amounts of cell-wall constituents decreased IR and eating time at the expense of ruminating time and also decreased the number of meals. Although in the present experiment diet did not affect the number of meals, the decreased IR at greater NDF and lesser starch contents between RGS, CON, and RCS, as well as the resulting longer meal duration, were in line with our hypothesis and with the results Deswysen et al. (1993) found with heifers fed grass and corn silage, even though the NDF content of grass and corn silage was lesser in the current experiment (grass silage 54.4 and $47.2 \%$ and corn silage 42.1 and $37.5 \%$ in early and late lactation, respectively) than in the experiment by Deswysen et al. (1993; 63 and $50 \%$, respectively). The ratio between NDF content in grass silage vs. corn silage was similar between both experiments, varying between 26 and $29 \%$ greater NDF contents in grass silage than in corn silage.

The effects on short-term feed intake behavior variables were in line with a decreased DMI of the RGS diet vs. the other treatments, probably related to the greater NDF content. Nevertheless, in spite of the similar NDF content of RGS and CSC, DMI was not decreased in CSC compared with CON and CNS. The reason for this is not clear, because both the relative amounts of $\mathrm{ADL}$ and $\mathrm{ADF}$ in $\mathrm{NDF}$, rumen $\mathrm{Kcl}$ of $\mathrm{NDF}$, and ED of NDF degradation characteristics were similar. Apparently, the way of distribution of NDF (through silage or concentrates) affects the effects on short-term feed intake behavior. This could be due to effects on particle size, as shown with chopped alfalfa silage by Beauchemin et al. (1994), although Allen (2000) only found significant effects of chop length on DMI in 3 out of 20 comparisons.

Miron et al. (2004) studied the effects of replacing a concentrate high in starch by a concentrate high in NDF on short-term feed intake behavior. Concentrates were fed separately from a TMR in 3 meals per day. Meal duration was not affected by concentrate type, but eating time and number of meals per day were lesser, whereas meal size was greater with the high-starch concentrate. Dry matter intake was lesser on the highstarch diet than on the high-NDF diet, which is mainly attributed to greater NDF in vitro digestibility in the high-NDF concentrate and potential larger in vivo ef- fects related to a lesser $\mathrm{pH}$ with the high-starch diet (Miron et al., 2004). In the present experiment, eating time (per day) and IR (per meal) differed between CSC and CNS, but DMI did not differ. This indicates that manipulating intake behavior does not necessarily lead to changes in DMI.

\section{Rumen Fermentation}

The TMR high in starch (RCS and CNS) were expected to have a lesser rumen $\mathrm{pH}$ than TMR high in NDF (RGS and CSC). However, effective OM degradability was hardly different between these treatments (Table 8). The DMI on the RGS treatment was lesser than on the RCS treatment (Table 5). Thus, although ED did not differ, the total supply of fermentable nutrients with RGS was lesser than with RCS, explaining the differences in $\mathrm{pH}$ and in the time $\mathrm{pH}$ was below 5.8 (Table 6). Moreover, IR per meal was greater in RCS than RGS, also contributing to the difference in time that $\mathrm{pH}$ was below 5.8. In contrast, there were no differences in DMI or IR between CSC and CNS, and given the similar effective OM degradability values, no differences in $\mathrm{pH}$ between CSC and CNS were observed.

Between TMR differing in concentrate component (CNS vs. CSC), only numerical differences were found in the time $\mathrm{pH}$ of rumen fluid was below 5.8 and in average $\mathrm{pH}$ of rumen fluid (Table 6 ). This was in line with the absence of a difference in DMI (Table 5) and OM content of the 2 TMR (Table 4) and only very small numerical effects on $\mathrm{ED}_{\mathrm{OM}}$ (Table 8) between CNS and CSC.

Although pool size of $\mathrm{OM}$ in late lactation was more than $20 \%$ less than in early lactation (Table 7), rumen fluid VFA concentration was almost $20 \%$ greater in late lactation (Table 6). This was not due to a smaller rumen fluid volume during late lactation, because DM content of rumen contents was $18.6 \%$ in early lactation and $17.2 \%$ in late lactation (data not shown). These results indicate that $\mathrm{OM}$ of the TMR in late lactation was fermented faster than in early lactation. From Table 7, it is clear that the greater $\mathrm{Kcl}$ of $\mathrm{OM}$ in late lactation is both the result of greater passage rate of material from the rumen, indicated by the Kcl of ADL, and from a greater fractional degradation rate of OM. Although no data are available on fractional degradation rate of $\mathrm{OM}$ in early lactation, faster fermentation of OM in the rumen may have increased VFA production rate to a greater extent than VFA absorption and passage rates. The absorption of VFA depends on the concentration of VFA in the rumen fluid, with in general an increase in the fractional absorption rate when $\mathrm{pH}$ decreases as VFA concentration in rumen fluid increases (Lopez 
et al., 2003), although an interaction between $\mathrm{pH}$ and VFA concentration has been observed (Dijkstra et al., 1993). Indicative of the build-up of the concentration of VFA in rumen fluid was the concentration of VFA in the rumen fluid at the start of the rumen evacuations: there was a difference between late lactation $(140 \mathrm{mM})$ and early lactation $(125 \mathrm{~m} M, P=0.006)$.

\section{Milk Production}

The replacement of NDF with starch in feed is expected to decrease the molar proportion of acetate and increase that of propionate (Bannink et al., 2006). The increase in NDF when the amount of grass silage in the TMR was increased coincided with an increase in the concentration of acetate in rumen fluid. The decreased milk fat content in RCS (Table 9) is directly related to the lesser acetate:propionate ratio and lesser $\mathrm{pH}$ in the rumen (Table 6), and both have been related to a depression of milk fat content, albeit through different mechanisms (Bauman and Griinari, 2003).

In early lactation, milk protein content was greater in RCS than in RGS, whereas intake of CP (calculated from DMI and CP content of the TMR) was lesser in RCS than in RGS. In both treatments, the DVE requirements were greater than DVE intake in early lactation (DVE intake-DVE requirements were less than 1 in both treatments, data not shown). The energetically more efficient microbial protein synthesis from corn silage than from grass silage (Givens and Rulquin, 2004) might explain the increase in milk protein with RCS. In late lactation, RCS did not result in an increase in milk protein, because intake of DVE was greater than the requirements (DVE intake-DVE requirements were 1.51 in RGS and 1.48 in RCS) in both treatments. In late lactation, milk protein was therefore more likely limited by the genetic potential for milk protein.

\section{CONCLUSIONS}

This study confirmed that short-term intake behavior is related to DMI and milk production but also showed that other factors play a role. The influence of type of roughage on short-term intake behavior was stronger than that of the type of concentrate.

\section{ACKNOWLEDGMENTS}

Bruno Vlaeminck is a postdoctoral fellow of the Fund for Scientific Research-Flanders (Brussels, Belgium) and in 2006 was in receipt of a Wageningen Institute of Animal Sciences (WIAS) research fellowship. Anja Riksten (Animal Nutrition Group, Wageningen University) is gratefully acknowledged for her help in estimating meal criteria and Henk den Hartigh from Schothorst Feed Research (Lelystad, the Netherlands) for his help in the starch analyses. Students Wibe Fokkink, Bart Fonken, Vronie de Boer, Miguel Fernandes, Giacomo Sisinni, and Benno Vaartjes are acknowledged for their involvement in the experiment, as are the farm staff of research farm De Ossekampen of Wageningen University and the laboratory staff of the Animal Nutrition laboratory. We thank the Product Board Animal Feed (PDV) and the Dutch Dairy Board (PZ) for the financial support of this experiment.

\section{REFERENCES}

Abijaoudé, J. A., P. Morand-Fehr, J. Tessier, P. Schmidely, and D. Sauvant. 2000. Diet effect on the daily feeding behaviour, frequency and characteristics of meals in dairy goats. Livest. Prod. Sci. 64:29-37.

Abrahamse, P. A., J. Dijkstra, B. Vlaeminck, and S. Tamminga. 2008. Frequent allocation of rotationally grazed dairy cows changes grazing behavior and improves productivity. J. Dairy Sci. 91:2033-2045.

Allen, M. S. 2000. Effects of diet on short-term regulation of feed intake by lactating dairy cattle. J. Dairy Sci. 83:1598-1624.

Bannink, A., J. Kogut, J. Dijkstra, J. France, E. Kebreab, A. M. Van Vuuren, and S. Tamminga, 2006. Estimation of the stoichiometry of volatile fatty acid production in the rumen of lactating cows. J. Theor. Biol. 238:36-51.

Bauman, D. E., and J. M. Griinari. 2003. Nutritional regulation of milk fat synthesis. Annu. Rev. Nutr. 23:203-227.

Beauchemin, K. A. 1991. Effects of dietary neutral detergent fiber concentration and alfalfa hay quality on chewing, rumen function, and milk production of dairy cows. J. Dairy Sci. 74:3140-3151.

Beauchemin, K. A., B. I. Farr, L. M. Rode, and G. B. Schaalje. 1994. Effects of alfalfa silage chop length and supplementary long hay on chewing and milk production of dairy cows. J. Dairy Sci. 77:1326-1339.

Bruining, M., R. Bakker, J. van Bruchem, and S. Tamminga. 1998. Rumen digesta kinetics in dairy cows fed grass, maize and alfalfa silage. 1. Comparison of conventional, steady-state and dynamic methods to estimate microbial degradation, comminution and passage of particles. Anim. Feed Sci. Technol. 73:37-58.

Coppock, C. E., C. H. Noller, and S. A. Wolfe. 1974. Effect of forageconcentrate ratio in complete feeds fed ad libitum on energy intake in relation to requirements by dairy cows. J. Dairy Sci. 57:13711380.

Dado, R. G., and M. S. Allen. 1994. Variation in and relationships among feeding, chewing, and drinking variables for lactating dairy cows. J. Dairy Sci. 77:132-144.

Dado, R. G., and M. S. Allen. 1995. Intake limitations, feeding behavior, and rumen function of cows challenged with rumen fill from dietary fiber or inert bulk. J. Dairy Sci. 78:118-133.

Deswysen, A. G., P. Dutilleul, J. P. Godfrin, and W. C. Ellis. 1993. Nycterohemeral eating and ruminating patterns in heifers fed grass or corn silage: Analysis by finite Fourier transform. J. Anim. Sci. $71: 2739-2747$.

DeVries, T. J., M. A. G. von Keyserlingk, and D. M. Weary. 2004 Effect of feeding space on the inter-cow distance, aggression, and feeding behavior of free-stall housed lactating dairy cows. J. Dairy Sci. 87:1432-1438.

DeVries, T. J., M. A. G. von Keyserlingk, D. M. Weary, and K. A. Beauchemin. 2003. Measuring the feeding behavior of lactating dairy cows in early to peak lactation. J. Dairy Sci. 86:33543361.

Dijkstra, J., H. Boer, J. Van Bruchem, M. Bruining, and S. Tamminga. 1993. Absorption of volatile fatty acids from the rumen of lactating dairy cows as influenced by volatile fatty acid concentration, $\mathrm{pH}$ and rumen liquid volume. Br. J. Nutr. 69:385-396.

Dulphy, J. P., B. Remond, and M. Theriez. 1980. Ingestive behaviour and related activities in ruminants. Pages 103-122 in Digestive 
Physiology and Metabolism in Ruminants. Y. Ruckebush and P. Thivend, ed. AVI Publishing Co., Westport, CT.

Friggens, N. C., B. L. Nielsen, I. Kyriazakis, B. J. Tolkamp, and G. C. Emmans. 1998. Effects of feed composition and stage of lactation on the short-term feeding behavior of dairy cows. J. Dairy Sci. $81: 3268-3277$.

Givens, D. I., and H. Rulquin. 2004. Utilisation by ruminants of nitrogen compounds in silage-based diets. Anim. Feed Sci. Technol. 114:1-18.

Grant, R. J., and J. L. Albright. 1995. Feeding behavior and management factors during the transition period in dairy cattle. J. Anim. Sci. 73:2791-2803

Huzzey, J. M., M. A. G. von Keyserlingk, and D. M. Weary. 2005. Changes in feeding, drinking, and standing behavior of dairy cows during the transition period. J. Dairy Sci. 88:2454-2461.

ISO. 2004. Animal Feeding Stuffs - Enzymatic determination of total starch content. ISO 15914:2004. International Organization for Standardization, Geneva, Switzerland.

Jung, H. G., and M. S. Allen. 1995. Characteristics of plant cell walls affecting intake and digestibility of forages by ruminants. J. Anim. Sci. $73: 2774-2790$.

Kertz, A. F., L. F. Reutzel, and G. M. Thomson. 1991. Dry matter intake from parturition to midlactation. J. Dairy Sci. 74:22902295.

Kolver, E. S., and M. J. de Veth. 2002. Prediction of ruminal pH from pasture-based diets. J. Dairy Sci. 85:1255-1266.

Littell, R. C., P. R. Henry, and C. B. Ammerman. 1998. Statistical analysis of repeated measures data using SAS procedures. J. Anim. Sci. 76:1216-1231.

Lopez, S., F. D. D. Hovell, J. Dijkstra, and J. France. 2003. Effects of volatile fatty acid supply on their absorption and on water kinetics in the rumen of sheep sustained by intragastric infusions. J. Anim. Sci. 81:2609-2616.

Melin, M., H. Wiktorsson, and L. Norell. 2005. Analysis of feeding and drinking patterns of dairy cows in two cow traffic situations in automatic milking systems. J. Dairy Sci. 88:71-85.

Miron, J., E. Yosef, M. Nikbachat, A. Zenou, E. Maltz, I. Halachmi, and D. Ben-Ghedalia. 2004. Feeding behavior and performance of dairy cows fed pelleted nonroughage fiber byproducts. J. Dairy Sci. $87: 1372-1379$

Newbold, J. R., E. A. Lewis, J. Lavrijssen, H. J. Brand, H. Vedder, and J. Bakker. 2006. Effect of storage time on ruminal starch degradability in corn silage. J. Anim. Sci. 84:190. (Abstr.)

Oldenbroek, J. K. 1984. Holstein Friesians, Dutch Friesians and Dutch Red and Whites on two complete diets with a different amount of roughage: Performance in first lactation. Livest. Prod. Sci 11:401-415.

Robinson, P. H., S. Tamminga, and A. M. van Vuuren. 1986. Influence of declining level of feed intake and varying the proportion of starch in the concentrate on rumen fermentation in dairy cows. Livest. Prod. Sci. 15:173-189.

Tamminga, S., W. M. van Straalen, A. P. J. Subnel, R. G. M. Meijer, A. Steg, C. J. G. Wever, and M. C. Blok. 1994. The Dutch protein evaluation system: The DVE/OEB-system. Livest. Prod. Sci 40:139-155.

Tas, B. M., H. Z. Taweel, H. J. Smit, A. Elgersma, J. Dijkstra, and S. Tamminga. 2006. Rumen degradation characteristics of perennial ryegrass cultivars during the growing season. Anim. Feed Sci. Technol. 131:102-119.

Taweel, H. Z., B. M. Tas, J. Dijkstra, and S. Tamminga. 2004. Intake regulation and grazing behavior of dairy cows under continuous stocking. J. Dairy Sci. 87:3417-3427.

Taweel, H. Z., B. M. Tas, H. J. Smit, A. Elgersma, J. Dijkstra, an S. Tamminga. 2005. Effects of feeding perennial ryegrass with an elevated concentration of water-soluble carbohydrates on intake, rumen function and performance of dairy cows. Anim. Feed Sci. Technol. 121:243-256.

Tempelman, R. J. 2004. Experimental design and statistical methods for classical and bioequivalence hypothesis testing with an application to dairy nutrition studies. J. Anim. Sci. 82:E162-E172.

Tolkamp, B. J., D. J. Allcroft, E. J. Austin, B. L. Nielsen, and I Kyriazakis. 1998. Satiety splits feeding behaviour into bouts. J. Theor. Biol. 194:235-250.

Tolkamp, B. J., N. C. Friggens, G. C. Emmans, I. Kyriazakis, and J. D. Oldham. 2002. Meal patterns of dairy cows consuming mixed foods with a high or a low ratio of concentrate to grass silage. Anim. Sci. 74:369-382

Tolkamp, B. J., and I. Kyriazakis. 1999. To split behaviour into bouts, log-transform the intervals. Anim. Behav. 57:807-817.

Van Es, A. J. H. 1975. Feed evaluation for dairy cows. Livest. Prod. Sci. 2:95-107.

van Knegsel, A. T. M., H. van den Brand, J. Dijkstra, S. Tamminga, and B. Kemp. 2005. Effect of dietary energy source on energy balance, production, metabolic disorders and reproduction in lactating dairy cattle. Reprod. Nutr. Dev. 45:665-688.

Yeates, M. P., B. J. Tolkamp, D. J. Allcroft, and I. Kyriazakis. 2001. The use of mixed distribution models to determine bout criteria for analysis of animal behaviour. J. Theor. Biol. 213:413-425. 